\title{
Identification of Historic Apple Trees in the Southwestern United States and Implications for Conservation
}

\author{
Kanin J. Routson ${ }^{1}$ \\ Arid Lands Resource Sciences, University of Arizona, 1955 East Sixth Street, \\ P.O. Box 210184, Tucson, AZ 85719
}

Ann A. Reilley, Adam D. Henk, and Gayle M. Volk
National Center for Genetic Resources Preservation, U.S. Department of
Agriculture, Fort Collins, CO 80521

Additional index words. Malus, simple sequence repeat, genetic diversity

\begin{abstract}
Many apple varieties commonly planted in the United States a century ago can no longer be found in today's orchards and nurseries. Abandoned farmsteads and historic orchards harbor considerable agrobiodiversity, but the extent and location of that diversity is poorly understood. We assessed the genetic diversity of 280 apple (Malus $\times$ domestica Borkh.) trees growing in 43 historic farmstead and orchard sites in Arizona, Utah, and New Mexico using seven microsatellite markers. We compared the samples to 109 cultivars likely introduced into the southwest in the late 19th and early 20th centuries. Genetic analysis revealed 144 genotypes represented in the 280 field samples. We identified 34 of these 144 genotypes as cultivars brought to the region by Stark Brothers Nursery and by USDA agricultural experiment stations. One hundred twenty of the total samples $(43 \%)$ had DNA fingerprints that suggested they were representative of these 34 cultivars. The remaining 160 samples-representing 110 genotypes-had unique fingerprints that did not match any of the fingerprinted cultivars. The results of this study confirm for the first time that a high diversity of historic apple genotypes remain in homestead orchards in the U.S. southwest. Future efforts targeting orchards in the southwest should focus on conservation for all unique genotypes as a means to sustain both cultural heritage and biological genetic diversity.
\end{abstract}

The late 19th century is often referred to as the golden years of apple growing in the United States (Calhoun, 1995; Hensley, 2005). Farmstead and kitchen orchards were planted with a wide variety of fruit trees to suit diverse family needs. Historically, rural livelihoods were maintained by growing apples and pears that ripened in summer, would "keep" all winter in the cold cellar, produce

Received for publication 16 Dec. 2008. Accepted for publication 6 Feb. 2009

This project was part of Kanin Routson's Master's research at Northern Arizona University. Thank you to Gary Nabhan, Thomas Sisk, David Ostergren, Gery Allan, and other staff at NAU who helped with this study. We also express our gratitude to all who have provided funding for this project: the National Park Service and the Margaret T. Morris Foundation. In addition, we are grateful to Lee Calhoun, Ram Fishman, and Philip Forsline for sending leaf samples of named varieties used in this study and to Christopher Richards for use of facilities at USDA-ARS-NCGRP. Lastly, we thank Gerard Geenen of the Plant Cytometry Services (Schijndel, The Netherlands) for determining ploidy for the samples and reference cultivars.

Mention of trade names or commercial products in this article is solely for the purpose of providing specific information and does not imply recommendation or endorsement by the U.S. Department of Agriculture.

${ }^{1}$ To whom reprint requests should be addressed; e-mailkjr53@email.arizona.edu. named apple cultivars introduced to or selected in North America.

Modern commercial apple production requires consistency of ripening time, quality retention during processing and shipping, and long storage life, and not all varieties can meet these criteria (Goland and Bauer, 2004). Market pressures have reduced the diversity of fruit trees once grown in small family orchards - where diversity of ripening time, sizes, textures, and flavors were celebrated - to only a few handfuls of commonly planted commercial cultivars. Currently, 11 apple cultivars account for over $90 \%$ of the apples sold in the United States, with 'Red Delicious' constituting $41 \%$ of this figure (Dennis, 2008). In The Fruit, Berry and Nut Inventory (Whealy, 2001) Kent Whealy lists $\approx 1500$ apple varieties currently available through U.S. nurseries, many of which have been developed through modern fruit breeding. This suggests a substantial decrease in the number of apple cultivars offered through U.S. nurseries over the past century $(77 \%$ by Ragan's calculations and $89 \%$ by Bussey's), although we do not know to what extent this naming actually represented genetically distinct cultivars.

Although the loss of on-farm diversity can be lasting, fruit trees have an advantage over annual crops because these trees can live to remarkably old ages, surviving some fads in consumer demand. Single apple trees have been known to live 150 years or longer. In many areas, it is still possible to find trees of "heirloom" cultivars once abundant at the beginning of the 20th century. Remnant orchards planted before the "modern era" of fruit production (Jackson, 2003) hang on tenaciously around abandoned farmsteads and historic orchards. Although farmstead trees often persist without their original names being retained, they represent a snapshot of the diversity of fruit varieties available over a century ago during the peak of fruit tree diversification.

Morphological and taxonomic traits typically used to differentiate between apple cultivars can be ambiguous as a result of the broad phenotypic variation under different environmental influences. Furthermore, many 19 th century apple cultivars are morphologically similar to one another and accurate descriptions are often lacking, making conventional identification methods difficult, if not impossible, for these century-old trees.

Genetic fingerprinting, including microsatellites, have become powerful and accurate tools for analyzing genetic diversity (Hammer et al., 2003). Microsatellite loci, or simple sequence repeats, are short nucleotide sequences of up to six basepairs repeated in tandem, head to tail, without interruption. They are highly polymorphic, codominant markers that have been detected in every organism thus far studied (Hancock, 1999). Gianfranceschi et al. (1998), Hokanson et al. (1998), and Hemmat et al. (2003) were instrumental in developing Malus-specific microsatellites in the United States. In Europe, Silfverberg-Dilworth et al. (2006) 
and the High-Quality Disease Resistant Apples for Sustainable Agriculture have been forefront in developing microsatellites for Malus. In a similar study in Spain, PereiraLorenzo et al. (2007) evaluated the genetic diversity of 114 Spanish apple cultivars comparing the local Spanish landrace genotypes with 26 commercial apple cultivars found in the region. Similar to this study, Pereira-Lorenzo et al. (2007) found high levels of genetic diversity in apple trees in northern Spain based on observed heterozygosity.

In this study, we sampled tissues from 280 apple trees from 43 historic sites within Arizona, Utah, and New Mexico to assess their diversity. Genotypes identified using seven highly variable markers were compared with reference genotypes of known cultivars. The term "historic" is used in this text to refer to farmstead and orchard sites planted during the late 19th and early 20th centuries, and the term "heirloom" refers to cultivars introduced during the 19th century and before as opposed to recent introductions developed through modern fruit breeding programs.

\section{Materials and Methods}

Field collections. We collected leaf samples from 280 apple trees located in 43 historic orchard sites on public and private (but not tribal) lands in Arizona, New Mexico, and Utah (Fig. 1). Sampling took place from June through September of 2007. We targeted places with presumed historic orchards and trees of visually differing morphologies. Local experts provided site location information. Sampling permission was obtained and samples were used only for this study, not for gene banking or crop improvement.

We focused sampling efforts primarily on historic farmstead and orchard sites dating back to the 1930s and earlier with priority given to trees planted before 1920. For a handful of the orchard sites such as Capitol Reef National Park, UT, and Slide Rock State Park, AZ, orchard planting dates could be found in historical documentation. Most of the orchard sites lacked written documentation, however, and we had to rely on oral history or visual determination of tree size and locality for approximate ages. We avoided sampling from seedling trees and rootstock trees where it appeared the original grafted top had died. The dry southwest climate limits establishment of naturalized seedling apple trees and many farmstead orchards in the southwest date to the late 19th to early 20th centuries, a time when few seedling orchards were planted in the United States. Leaf samples were collected only from trees that were visibly different from other trees at the same site to avoid repeat sampling of cultivars. However, this was not always possible for trees without fruit.

Global positioning system locations for the sample trees (Garmin eTrex-Vista handheld unit; Garmin, Olathe, KS) in UTM (Nad1983) coordinates were recorded, and small alumi-

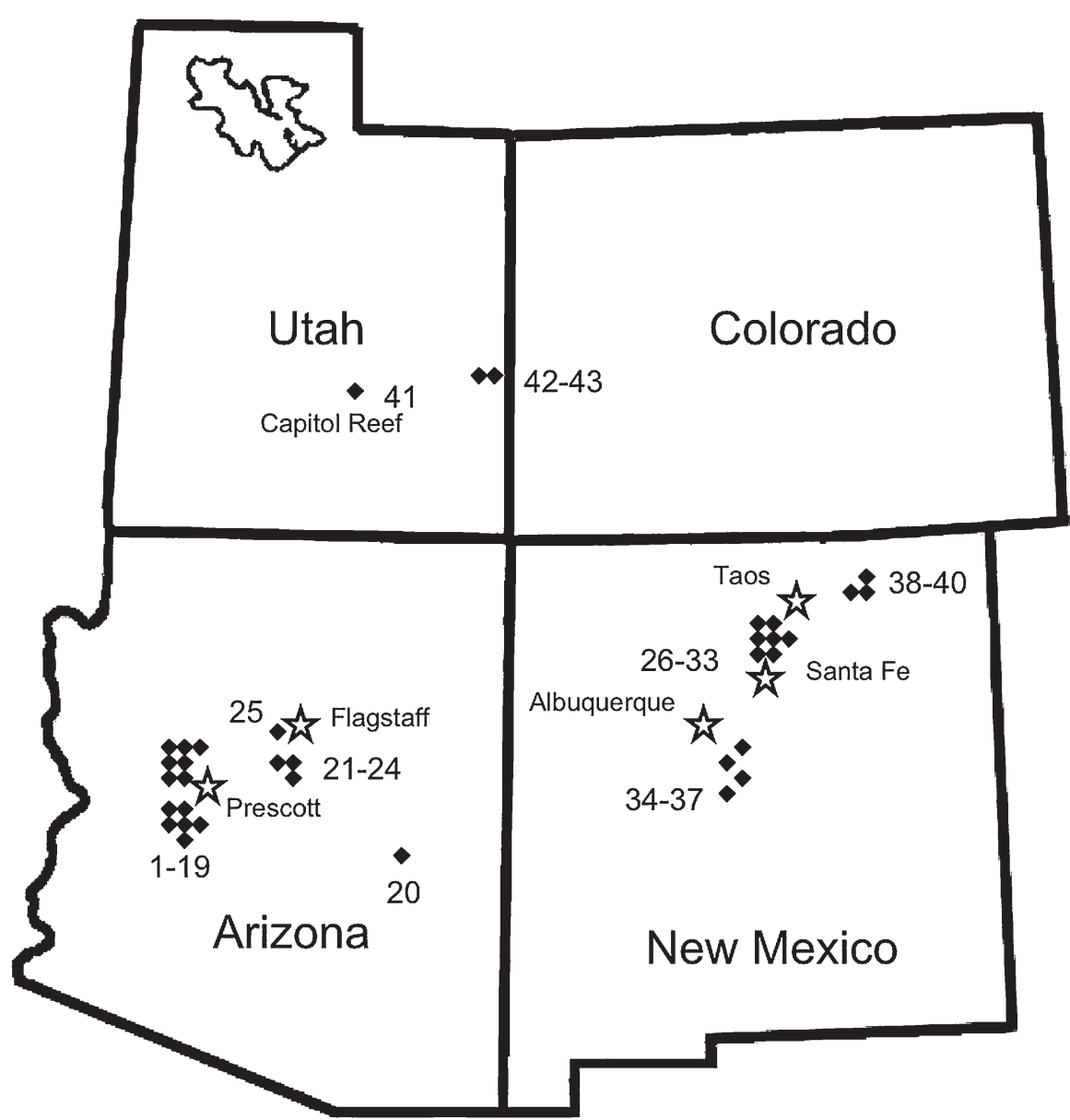

Fig. 1. Historic apple collection sites (numbered and noted by diamonds) in Utah, Arizona, and New Mexico were sampled. Cities are provided for reference purposes (star designation).

num tags were nailed to the trees with a numerical identifier. For each sample, $\approx 50$ $\mathrm{mg}$ of fresh leaf tissue was placed into a 96well plate and frozen at $-20^{\circ} \mathrm{C}$ until extraction. Known cultivars were obtained from the USDA-ARS-Plant Genetic Resources Unit, Geneva, NY (PGRU). Varieties that were not available through the Geneva facility were obtained from Lee Calhoun of Calhoun's Nursery in Pittsboro, NC; Ram Fishman of Greenmantle Nursery in Garberville, CA; and Gordon Tooley of Tooley's Trees in Truchas, NM. Leaf samples were processed in the same manner as the unknown samples.

Microsatellite analysis. The genetic analysis of the 280 samples and 109 cultivars was performed following procedures described in Volk et al. (2005). We extracted genomic DNA from the leaf samples using Qiagen DNeasy 96 plant kits (Qiagen, Valencia, CA). Two separate sets of DNA were extracted from each sample and run independently. Malus-specific microsatellites were amplified using unlinked primers (GD12, GD15, GD96, GD100, GD142, GD147, and GD162) as described by Hokanson et al. (1998) and by Hemmat et al. (2003). Forward primers were labeled with either IRD700 or IRD800 infrared florescent dyes (MWG-Biotech, High Point, NC). Unlabeled reverse primers were obtained from IDT (Coralville, IA).
Polymerase chain reactions (PCRs) were carried out in $15 \mu \mathrm{L}$ total volume. Each $15 \mu \mathrm{L}$ reaction contained: $0.3 \mu \mathrm{L}$ GoTaq ${ }^{\circledR}$ Flexi Taq Polymerase (Promega, Madison, WI; 5 units/ $\mu \mathrm{L}), 3 \mu \mathrm{L}$ Promega $5 \times$ Colorless GoTaq ${ }^{\circledR}$ Flexi Buffer (10 mm Tris- $\mathrm{HCl}, 50 \mathrm{~mm} \mathrm{KCl}$, and $0.5 \%$ Triton X-100), $1.5 \mu \mathrm{L}$ of $0.25 \mathrm{~mm} \mathrm{MgCl}_{2}$, and $1.5 \mu \mathrm{L}$ of $0.25 \mathrm{~mm}$ dNTPs. Forward and reverse primers were added to a final concentration of $0.25 \mathrm{pM} /$ reaction except for GD12 at $0.3 \mathrm{pM} /$ reaction and GD100 at $0.5 \mathrm{pM} /$ reaction.

Genomic DNA, isolated as described previously, was added at $0.5 \mathrm{ng}$ to $5 \mathrm{ng} /$ reaction. Reaction volumes were adjusted to $15 \mu \mathrm{L}$ using sterile distilled $\mathrm{H}_{2} 0$. PCR reactions were multiplexed with the following primer sets: GD12, GD100; GD142, GD147, GD162; and GD15, GD96 run together. PCR was carried out using MJ Research PTC 200 Thermocycler (Reno, NV). Amplifications were done using touchdown PCR, in which the thermocycler reduced the annealing temperature $1^{\circ}$ every cycle, starting at $63{ }^{\circ} \mathrm{C}$ and ending at $54{ }^{\circ} \mathrm{C}$, followed by an annealing temperature of $55^{\circ} \mathrm{C}$ for 18 cycles and ending with a $2 \min 72{ }^{\circ} \mathrm{C}$ extension.

PCR products were diluted 1:1 with a loading buffer of formamide bromophenol blue loading buffer and were denatured at $95{ }^{\circ} \mathrm{C}$ for $5 \mathrm{~min}$. Denatured products were diluted 1:10 with additional loading buffer. 
Table 1. Ploidy, origin, and probable date of release are provided for 109 apple cultivars introduced to the southwestern United States. ${ }^{2}$

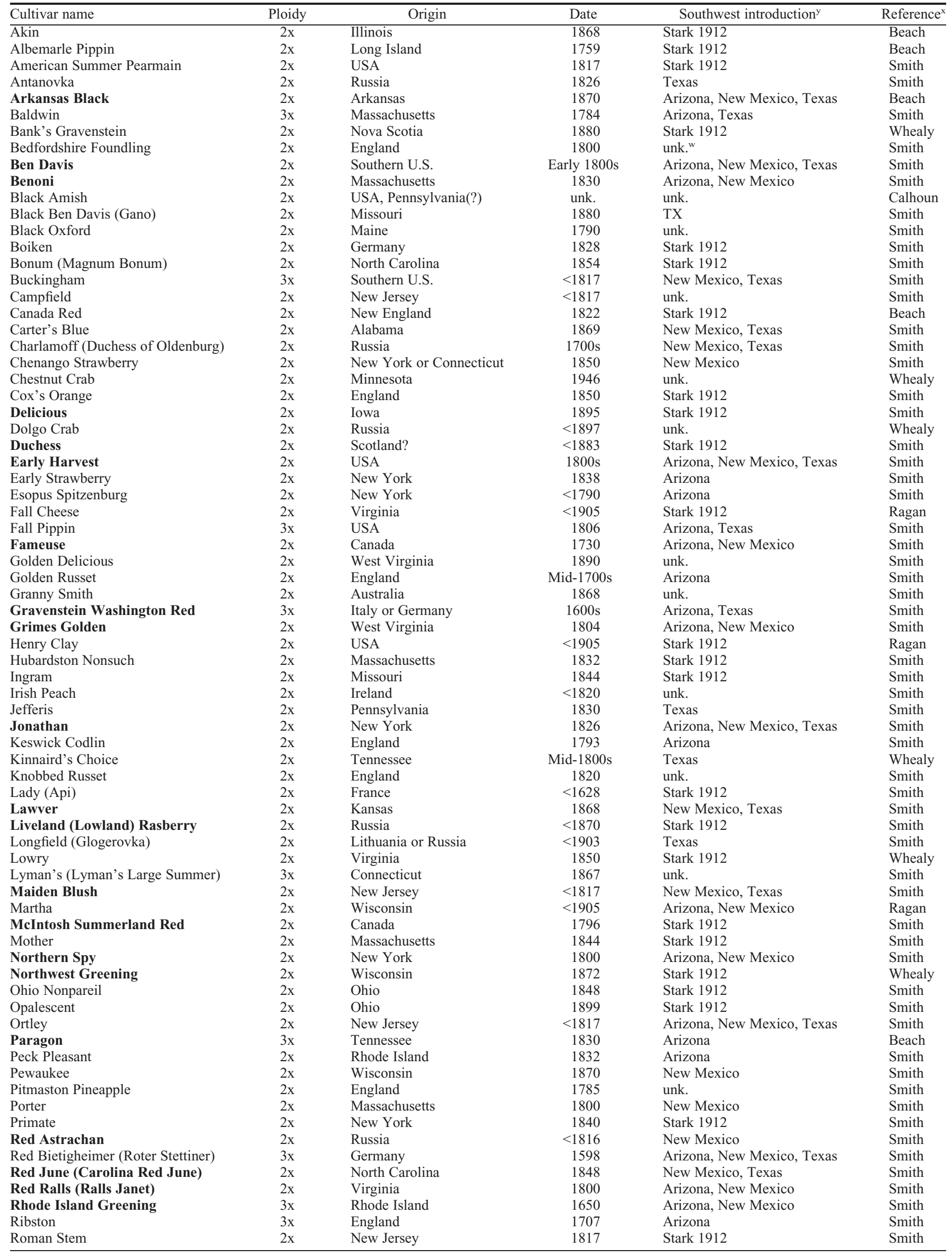


Table 1. (Continued) Ploidy, origin, and probable date of release are provided for 109 apple cultivars introduced to the southwestern United States. ${ }^{\mathrm{Z}}$

\begin{tabular}{|c|c|c|c|c|c|}
\hline Cultivar name & Ploidy & Origin & Date & Southwest introduction ${ }^{\mathrm{y}}$ & Reference $^{\mathrm{x}}$ \\
\hline Rome Beauty law & $2 x$ & Ohio & 1848 & Arizona, New Mexico, Texas & Smith \\
\hline Rosemary Russet & $2 x$ & England & 1831 & unk. & Smith \\
\hline Roxbury Russet & $3 x$ & Massachusetts & 1649 & Arizona & Beach \\
\hline Shockley & $2 x$ & Georgia & 1854 & New Mexico, Texas & Smith \\
\hline Smith's Cider & $2 x$ & Pennsylvania & $<1817$ & Arizona, Texas & Smith \\
\hline Sops of Wine & $2 x$ & England & 1831 & New Mexico & Smith \\
\hline Stark & $3 x$ & Ohio & 1867 & Arizona & Smith \\
\hline Stayman & $3 x$ & Kansas & 1875 & Stark 1912 & Smith \\
\hline Summer Champion & $2 x$ & Arkansas & $1897 ?$ & Stark 1912 & Calhoun \\
\hline Swaar & $2 \mathrm{x}$ & New York & 1804 & Arizona, New Mexico & Smith \\
\hline Sweet Bough (Bough) & $2 x$ & USA & 1817 & Arizona, Texas & Smith \\
\hline Sweet Dixon & $2 x$ & North Carolina & $<1905$ & New Mexico, Texas & Ragan \\
\hline Tolman Sweet & $2 x$ & USA & 1822 & Arizona, New Mexico & Smith \\
\hline Tompkin's King & $3 x$ & New Jersey & 1804 & Stark 1912 & Smith \\
\hline Transcendent Crab & $3 x$ & unk. & $<1844$ & New Mexico & Bussey \\
\hline Twenty Ounce Pippin & $2 x$ & Connecticut or New York & 1844 & Texas & Smith \\
\hline Virginia Crab (Hewes) & $2 x$ & Virginia & $<1803$ & unk. & Bussey \\
\hline Virginia Beauty & $2 x$ & Virginia & 1826 & Stark 1912 & Whealy \\
\hline Vixin Crab & $3 x$ & unk. & unk. & unk. & unk. \\
\hline Wagner & $2 x$ & New York & 1791 & Stark 1912 & Smith \\
\hline Wealthy & $2 x$ & minnesota & 1860 & New Mexico, Texas & Smith \\
\hline Westfield Seek No Further & $2 \mathrm{x}$ & Massachusetts & 1796 & unk. & Smith \\
\hline White Astrachan & $3 x$ & Sweden or Russia & 1748 & Arizona & Smith \\
\hline White Winter Pearmain & $2 x$ & USA & 1849 & Stark 1912 & Smith \\
\hline Wickson & $2 x$ & California & 1944 & unk. & Whealy \\
\hline Winesap & $2 \mathrm{x}$ & New Jersey & $<1817$ & Arizona, New Mexico, Texas & Smith \\
\hline Winter Banana & $2 x$ & Indiana & 1876 & unk. & Smith \\
\hline Winthrop Greening & $2 x$ & Maine & 1800 & unk. & Smith \\
\hline Wolf River & $2 \mathrm{x}$ & Wisconsin & 1875 & New Mexico & Smith \\
\hline Yarlington Mill & $2 x$ & England & unk. & unk. & Whealy \\
\hline Yates & $2 \mathrm{x}$ & Georgia & 1813 & Stark 1912 & Smith \\
\hline Yellow Bellflower & $2 x$ & New Jersey & $<1817$ & Arizona, Texas & Smith \\
\hline Yellow Newtown Pippin ${ }^{w}$ & $2 \mathrm{x}$ & Long Island & 1759 & unk. & Beach \\
\hline Yellow (White) Transparent & $2 x$ & Russia or Baltic States & $1800 \mathrm{~s}$ & Texas & Smith \\
\hline York Imperial & $2 x$ & Pennsylvania & 1830 & Arizona, New Mexico & Smith \\
\hline
\end{tabular}

${ }^{\mathrm{z}}$ Cultivars identified in bold were identified in historic farmsteads.

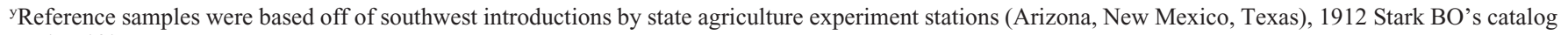
entries, if known.

${ }^{x}$ Origins and probable date of release are based on Beach (1905), Bussey (in press), Calhoun (1995), Ragan (1905), Smith (1971), and Whealy (2001).

wUnknown.

Diluted products were loaded on gels $(6.5 \%$ KB Plus acrylamide; LI-COR, Lincoln, NE) and run in $1 \times$ TBE buffer ( $89 \mathrm{~mm}$ Tris, $89 \mathrm{~mm}$ boric acid, and $20 \mathrm{~mm}$ EDTA) for $1 \mathrm{~h}, 45 \mathrm{~min}$ at $1500 \mathrm{~V}, 40 \mathrm{~W}, 40 \mathrm{~mA}$, and $45^{\circ} \mathrm{C}$ in a LICOR 4200 DNA Sequencer. Digital images of the gels collected by LI-COR Saga Generation 2 software were manually analyzed using Saga software. Each allele at each locus was manually scored in Saga before being compared with the duplicate sample.

Ploidy was determined using flow cytometry by Gerard Geenen of the Plant Cytometry Services, Schijndel, The Netherlands.

Microsatellite data analysis. Genotypes for the 280 samples and the 109 cultivars were compared manually in Microsoft Excel 2004 for Mac, Version 11.3.7 (Microsoft, Redmond, WA). Allele frequencies and observed and expected heterozygosities were computed using GenAlEx version 6 (Peakall and Smouse, 2006). Principal component analysis (PCA) ordinations were preformed using PC-ORD version 4.0 (MjM Software Design, Gleneden Beach, OR).

\section{Results and Discussion}

We found considerable genetic diversity in historic southwest orchard and farmstead sites. The "unknown" apple trees were com- pared with 109 known cultivars introduced into the southwest in the late 19th century by USDA agricultural experiment stations and by Stark Brother's Nursery, the largest mail order nursery during the late 19th and early 20th centuries. DNA fingerprints revealed that 120 of the 280 sample trees were indistinguishable from the fingerprints of 34 cultivars (Tables 1 and 2 ). The remaining 160 historic tree samples did not match any of the reference cultivars. These 160 samples represented 110 unique genotypes. These unknown genotypes could be regionally unique cultivars, local seedlings, cultivars extinct from the nursery trade, or extant cultivars originally from other regions that have not been recorded as being introduced into the southwest. For two samples, the duplicate genotypes did not match, suggesting different DNA source material. This may have been a result of leaves being collected from vegetative rootstock and from the grafted tree or a result of human error. Both samples were discarded from the study. In total, the 280 historic trees represented 144 distinct genotypes.

Only five of the 34 identified cultivars appeared to be commonly distributed. 'Ben Davis', 'Delicious', 'Grimes Golden', 'Jonathan', and 'Winesap' each represented more than four trees in the study found at multiple locations. A number of trees matched genotypes of named cultivars for all but one or two alleles at the locus GD100 (Table 2). It is not known if these 1- or 2-bp shifts represent morphologically different varieties or were a result of error during allele scoring.

The seven microsatellites were sufficient to differentiate between most samples and cultivars in this study. However, several of the cultivars had identical fingerprints. This suggests that these cultivar names are synonyms of the same cultivar, are close sport mutations not differentiable by these microsatellites (see Hokanson et al., 1998), or are mislabeled at their source nursery or genebank location. Named sets of cultivars Albemarle Pippin and Yellow Newtown Pippin, Early Strawberry and Yates, Fameuse and Canada, and Maiden Blush and Chenango Strawberry were indistinguishable from each other.

Ploidy results revealed 24 of the 280 samples $(8.6 \%)$ were triploid $(3 \mathrm{x}=51)$, whereas the remaining $91.4 \%$ were diploid $(2 \mathrm{x}=34)$. Triploids arise spontaneously in $2 \times$-by- $2 \times$ crosses and typically have larger fruit than diploid apple trees (Ferree and Warrington, 2003). Based on field observations, many of the triploids in this study appear to be late-ripening, large-fruited winter apples. 
Table 2. Identification of cultivars identified in historic farmsteads in the southwestern United States.

\begin{tabular}{|c|c|c|c|c|c|c|}
\hline Cultivar & $\begin{array}{c}\text { Trees } \\
\text { identified (no.) }\end{array}$ & Land ownership ${ }^{z}$ & Orchard type ${ }^{y}$ & $\begin{array}{c}\text { Present } \\
\text { condition }^{\mathrm{x}}\end{array}$ & $\begin{array}{c}\text { Nursery } \\
\text { sources }^{\mathrm{w}} \text { (no.) }\end{array}$ & Use \\
\hline Arkansas Black & 3 & AZSPS, private & Commercial and farm & Maintained & 35 & Cider, fresh eating, and cooking \\
\hline Ben Davis & 16 & NFS and private & Commercial and farm & Abandoned & 10 & Long storage life \\
\hline Benoni & 2 & Private & Commercial & Abandoned & 6 & Dessert \\
\hline Delicious & 12 & NFS and private & Commercial and farm & Maintained & 36 & Fresh eating and dessert \\
\hline Duchess & 1 & Private & Farm & Maintained & 17 & Cooking, poor storage life \\
\hline Early harvest ${ }^{\mathrm{v}}$ & 1 & Private & Farm & Abandoned & 18 & Cooking \\
\hline Fameuse & 2 & Private & Farm & Abandoned & 19 & Cider, fresh eating, and cooking \\
\hline Gravenstien, WA Red & 1 & Private & Farm & Abandoned & 31 & Cooking and cider \\
\hline Grimes Golden ${ }^{v}$ & 6 & NPS and private & Commercial and farm & Maintained & 35 & Cider and dessert \\
\hline Jonathan & 17 & NFS and private & Commercial and farm & Maintained & 44 & Cooking and fresh eating \\
\hline Lawver $^{v}$ & 1 & Private & Commercial & Abandoned & 1 & Fresh eating \\
\hline Liveland Rasberry & 1 & NFS & Farm & Abandoned & 11 & Fresh eating \\
\hline Maiden Blush & 2 & Private & Commercial & Abandoned & 16 & Cider, fresh eating, cooking \\
\hline McIntosh Summerland & 1 & Private & Farm & Abandoned & 46 & Cider, fresh eating, cooking \\
\hline Northern Spy & 1 & Private & Commercial & Abandoned & 39 & Cider, fresh eating, and cooking \\
\hline Northwest Greening & 2 & Private & Farm & Maintained & 15 & Winter cooking apple \\
\hline Paragon & 2 & AZSPS and private & Farm & Maintained & 1 & Winter cooking apple \\
\hline Red Astrachan ${ }^{v}$ & 2 & NFS and private & Commercial and farm & Abandoned & 18 & Fresh eating and cooking \\
\hline Red June & 1 & NFS & Farm & Abandoned & 19 & Cider, fresh eating, and cooking \\
\hline Red Ralls & 3 & Private & Farm & Maintained & 11 & Fresh eating \\
\hline Rhode Island Greening ${ }^{\vee}$ & 3 & NPS and private & Commercial and farm & Maintained & 12 & Winter cooking apple \\
\hline Rome Beauty Law & 2 & Private & Farm & Abandoned & 11 & Cooking and cider \\
\hline Stayman & 3 & Private & Farm & Maintained & 24 & Winter cooking and cider apple \\
\hline Tolman Sweet ${ }^{\mathrm{v}}$ & 2 & Private & Commercial and farm & Abandoned & 17 & Cider, fresh eating, and cooking \\
\hline Transcendent Crab & 1 & NFS & Farm & Abandoned & 2 & Cooking \\
\hline Wagner & 2 & NFS & Farm & Abandoned & 8 & Cider, fresh eating, and cooking \\
\hline Wealthy $^{\mathrm{v}}$ & 1 & NFS & Farm & Abandoned & 24 & Cider, fresh eating, and cooking \\
\hline Westfield Seek No Furtherv & 4 & NFS & Farm & Abandoned & 16 & Dessert \\
\hline White Astrachan ${ }^{v}$ & 3 & NFS and private & Commercial and farm & Abandoned & 2 & Fresh eating and dessert \\
\hline Winesap & 13 & Private & Commercial and farm & Abandoned & 23 & Cider, fresh eating, and cooking \\
\hline Winter Banana & 1 & NFS & Farm & Abandoned & 27 & Cider \\
\hline Wolf River & 4 & AZSPS and private & Commercial and farm & Maintained & 31 & Cooking \\
\hline Yellow Bellflower & 3 & NFS & Farm & Abandoned & 16 & Winter cooking apple \\
\hline Yellow Transparent & 1 & Private & Farm & Abandoned & 36 & Fresh eating and cooking \\
\hline
\end{tabular}

High levels of observed heterozygosity (0.92 for GD142, 0.90 for GD162, and 0.88 for GD147 and GD96) in the samples suggest that relatively high levels of genetic diversity are represented (Table 3). Heterozygosity was calculated from a sample size of 144 individuals, representing each of the 144 distinct genotypes found growing in the southwest. Observed heterozygosity was calculated by dividing the number of heterozygotes at a locus by the number of individuals surveyed. Expected heterozygosity assumes Hardy-Weinberg equilibrium but is included as a reference. The multiplicative probability of a multilocus genotype determines the power of discrimination; the high heterozsygosity of the sampled loci therefore makes the probability of distinctly different genotypes being identical at all seven microsatellite loci very slight. Microsatellite GD100 had $6 \%$ missing data as a result of poor amplification during PCR for several samples. We chose not to score this allele in these cases to avoid potential scoring error. Heterozygosity and allele frequencies should be interpreted with dubiety for this allele.

PCA was performed on the samples to visualize the genetic difference between apple genotypes (Fig. 2). In the PCA ordination, the two distinct clusters appear to be the

Table 3. Sample size, number of alleles, observed heterozygosity, and expected heterozygosity were calculated for samples with unique genotypes.

\begin{tabular}{lcccc}
\hline $\begin{array}{l}\text { Microsatellite } \\
\text { marker }\end{array}$ & $\begin{array}{c}\text { Sample } \\
\text { size number }\end{array}$ & $\begin{array}{c}\text { Number of } \\
\text { alleles }\end{array}$ & $\begin{array}{c}\text { Observed } \\
\text { heterozygosity }\end{array}$ & $\begin{array}{c}\text { Expected } \\
\text { heterozygosity }\end{array}$ \\
\hline GD12 & 144 & 11 & 0.833 & 0.751 \\
GD15 & 144 & 2 & 0.021 & 0.021 \\
GD96 & 144 & 14 & 0.875 & 0.853 \\
GD100 & 134 & 9 & 0.485 & 0.814 \\
GD142 & 144 & 13 & 0.924 & 0.864 \\
GD147 & 144 & 12 & 0.868 & 0.817 \\
GD162 & 144 & 13 & 0.896 & 0.827 \\
\hline
\end{tabular}

result of the presence of two larger alleles at marker GD12 (182 and 190 bps) instead of the more common 148- to 162-bp length alleles. Such clustering could be indicative of a shared genetic heritage between genotypes in the upper left cluster, although there does not appear to be any morphological association with the groups.

Unknown genotypes were labeled in the PCA with a state prefix attached to the end of the sample number to show possible associations of geographic origin to genotype. Geographic separation of samples would indicate that different sources of apple trees were grown in the various regions. Spanish priests, explorers, and settlers introduced apple trees to New Mexico as early as the 17th century
(Dunmire, 2004) as did the Archbishop Lamy of Santa $\mathrm{Fe}$ in the 19th century (Horgan, 1975). Geographic differentiation could also imply different apple preferences associated with different regions. However, there was no apparent genetic separation by geographic origin among samples. The historic trees in the southwest might all share the same recent parents, or the parent diversity could have been obscured by small sample size. Efforts were made to avoid seedling apple trees during sampling. As mentioned in the "Materials and Methods" of this article, we focused sampling efforts on grafted as opposed to seedling trees; however, a small percentage of the samples are likely to be of seedling origin and not named cultivars. Seedling trees 


\section{SAMPLES}

\section{$00 \mathrm{ABZ}$}

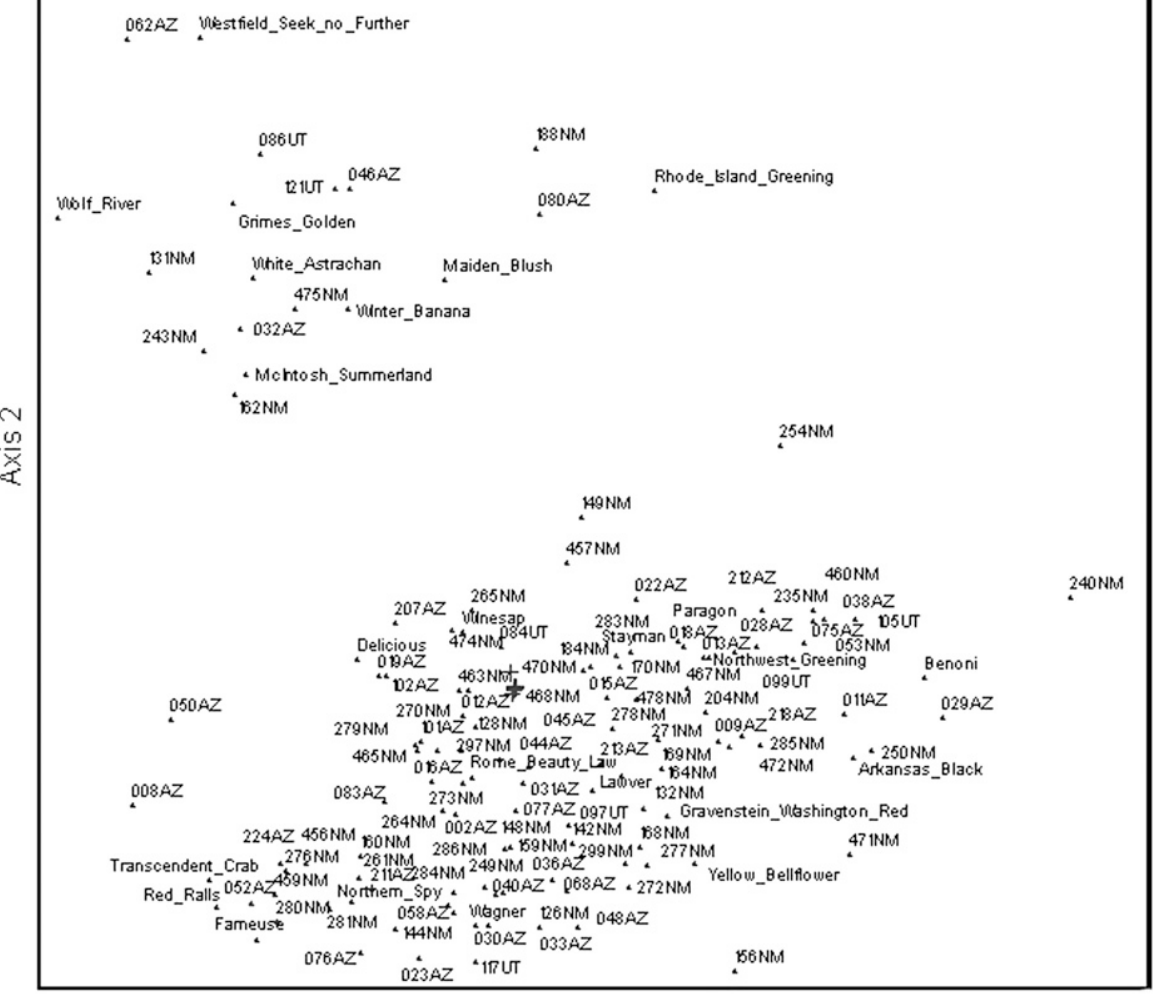

Axis 1

Fig. 2. Principal component analysis of unique apple genotypes. Sample numbers and state of origin are provided for unknown varieties and names are provided for known varieties.

would not share the same "heirloom" status as named 19th century cultivars but may still possess useful traits or local adaptations.

For this study, we fingerprinted cultivars from the USDA National Germplasm Collection and from private nurseries to compare with the unknown samples. We restricted the number of reference cultivars to 109 likely introduced into the southwest. The existence of a DNA fingerprint database for correctly identified fruit tree cultivars such as those at the PGRU would allow studies such as this one to answer more questions about the identities of the many unknown apple trees growing on abandoned farms and in parks and forests across the country.

Apple plantings in a number of orchards and farmsteads cultivated in the 19th and early 20th centuries in the U.S. southwest still survive, although many have been abandoned. From 43 historic sites, 280 apple trees were sampled and compared with 109 cultivars at the PGRU and in private nurseries using microsatellite analysis. The 280 samples yielded 34 named cultivars and 110 unique genotypes. These results suggest that the historic orchards in the southwest had a high diversity of genotypes. Additional genetic fingerprinting of apple cultivars in the USDA
PGRU will potentially enable us to identify the unknowns in this survey. Until such work is undertaken, these unknown genotypes should be conserved and analyzed for useful traits.

\section{Literature Cited}

Beach, S.A. 1905. The apples of New York. Volumes I \& II. Report of the New York Agriculture Experiment Station for the year 1903. J.B. Lyon Company, Albany, NY.

Bussey, D. The apple in North America: A register of apple varieties listed in North American publications from 1802-1980, based on nomenclature of the apple. U.S. Department of Agriculture Division of Plant Industry Bulletin \#56. Compiled by W.H. Ragan, 1905 (in press).

Calhoun, C.L. 1995. Old southern apples. McDonald and Woodward Publishing Company, Blacksburg, VA.

Dennis, F.G., Jr. 2008. Malus $\times$ domestica: Apple, p. 661-674. In: Janick, J. and R.E. Paull (eds.) The encyclopedia of fruit and nuts. CABI Publishing, Cambridge, MA.

Dunmire, C.C. 2004. Gardens of new Spain: How Mediterranean plants and foods changed America. University of Texas Press, Austin, TX.

Ferree, D.C. and I.J. Warrington. 2003. Apples: Botany, production and uses. CABI Publishing, Cambridge, MA.

Giafranceschi, L., N. Seglias, R. Tarchini, M. Komjane, and C. Gessler. 1998. Simple sequence repeats for the genetic analysis of apple. Theor. Appl. Genet. 96:1096-1076.

Goland, C. and S. Bauer. 2004. When the apple falls close to the tree: Local food systems and the preservation of diversity. Renewable Agricultural Food Systems 19:228-236.

Hammer, K., N. Arrowsmith, and T. Gladis. 2003. Agrobiodiversity with emphasis on plant genetic resources. Naturwissenschaften 90:241-250.

Hancock, J.M. 1999. Microsatellites and other simple sequences: Genomic context and mutational mechanisms, p. 1-23. In: Goldstein, D.B and C. Schlötterer (eds.). Reprinted in 2003. Microsatellites: Evolution and applications. Oxford University Press, Oxford, UK.

Hedrick, U.P. 1950. A history of horticulture in America to 1860 . Oxford University Press, Oxford, UK.

Hemmat, M.S.K.B. and N.F. Weeden. 2003. Mapping and evaluation of Malus $\times$ domestica microsatellites in apple and pear. J. Amer. Soc. Hort. Sci. 128:515-520.

Hensley, T. 2005. A curious tale: The apple in North America, p. 5-15. In: Hanson, B. (ed.). The best apples to buy and grow. Brooklyn Botanic Garden, Inc, Brooklyn, NY.

Hokanson, S.C., A.K. Szewc-McFadden, W.F. Lamboy, and J.R. McFerson. 1998. Microsatellite (SSR) markers reveal genetic identities, genetic diversity and relationships in Malus $\times$ domestica Borkh. core subset collection. Theor. Appl. Genet. 97:671-683.

Horgan, P. 1975. Lamy of Santa Fe: His life and times, a biography. Farrar, Straus \& Giroux, New York, NY.

Jackson, J.E. 2003. Biology of apples and pears. Cambridge University Press, Cambridge, UK.

Peakall, R. and P.E. Smouse. 2006. GENALEX 6: Genetic analysis in Excel. Population genetic software for teaching and research. Mol. Ecol. Notes 6: 288-295. 14 Nov. 2007. <http://www. anu.edu.au/BoZo/GenAlEx/>.

Pereira-Lorenzo, S., A.M. Ramos-Cabrer, and M.B. Díaz-Hernández. 2007. Evaluation of genetic identity and variation of local apple cultivars (Malus $\times$ domestica Borkh.) from Spain using microsatellite markers. Genet. Resources Crop Evol. 54:405-420.

Ragan, W.H. 1905. Nomenclature of the apple: A catalogue of the known varieties referred to in American publications from 1804 to 1904. USDA-BPI Bulletin \# 56. Government Printing Office, Washington, DC

Silfverberg-Dilworth, E., C.L. Matasci, W.E. Van de Weg, M.P. Van Kaauwen, M. Walser, L.P. Kodde, V. Soglio, L. Gianfranceschi, C.E. Durel, F. Costa, T. Yamamoto, B. Koller, C. Gessler, and A. Patocchi. 2006. Microsatellite markers spanning the apple (Malus $\times$ domestica Borkh.) genome. Tree Genetics \& Genomes 2:202-224.

Smith, M.W.G. 1971. National apple register of the United Kingdom. London Ministry of Agriculture, Fisheries and Food. 2002 reprint by Castlepoint Press, Colvend, UK.

Volk, G.M., C.M. Richards, A.A. Reilley, A.D. Henk, P.L. Forsline, and H.S. Aldwinckle. 2005. Ex situ conservation of vegetatively propagated species: Development of a seedbased core collection for Malus sieversii. J. Amer. Hort. Sci. 130:203-210.

Whealy, K. 2001. Fruit, berry, and nut inventory. 3rd Ed. Seed Savers Exchange, Decorah, IA. 